\title{
Etiology and pathology of epidermal papillomas in allogynogenetic crucian carp Carassius auratus gibelio (o) $\times$ Cyprinus carpio var. singuonensis $\left(0^{\prime}\right)$
}

\author{
Hongda $\mathrm{Lu}^{1, *}$, Guanglai Zhu' ${ }^{1}$, Liping Fan' ${ }^{2}$, Lianyi Zhang ${ }^{1}$ \\ ${ }^{1}$ College of Fisheries and Life, Shanghai Ocean University, Shanghai 201306, PR China \\ ${ }^{2}$ Fisheries Technical Advice Station of Chongming County of Shanghai, Shanghai 202150, PR China
}

\begin{abstract}
Allogynogenetic crucian carp Carassius auratus gibelio (o) $\times$ Cyprinus carpio var. singuonensis $\left(0^{\prime}\right)$ is one of the main freshwater aquaculture species in China. In recent years, epidermal papillomas have been observed on the scales, fins and opercula of adult fish in many fish farms in the Chongming county of Shanghai, China. The disease appears in the late autumn of the first year and becomes more severe in winter. It gradually regresses in the late spring or summer of the second year, as water temperature increases. Our study revealed that the disease pathogen was likely to be a herpes-like virus, as indicated by enveloped viral particles in the cytoplasm, empty capsids in the nucleus and a virus-like morphology of the pathogen. The size of the enveloped herpes-like virus was $118.18 \pm 10.53(\mathrm{SD}) \mathrm{nm}(\mathrm{n}=22)$ and its nucleocapsid was $78.64 \pm 7.74 \mathrm{~nm}(\mathrm{n}=22)$ in diameter. Histopathological examination of tumours revealed that both epithelial and stromal cells proliferated to form papillomas. The nuclei of epithelial tumour cells were irregular in shape and in size. Most of the mucous cells were located in clusters near the middle of each papilloma. Cytoplasmic organelles were sparse in tumour cells. Numerous granulocytes and lymphocytes infiltrated into the tumour tissue. There were no inclusion bodies in the cytoplasm and nuclei of tumour cells. The lesions only occurred in adult allogynogenetic crucian carp, even though they were cultured together with other fish species. There was marked variation in incidence: in some ponds, only a few fish were affected, while the incidence was up to $90 \%$ in other ponds.
\end{abstract}

KEY WORDS: Epidermal papilloma $\cdot$ Histopathology $\cdot$ Etiology $\cdot$ Herpes-like virus $\cdot$ Carassius auratus gibelio (o) $\times$ Cyprinus carpio var. singuonensis $\left(0^{7}\right)$

\section{INTRODUCTION}

Allogynogenetic crucian carp (ACC) (Zhou \& Liu 2004 ) is a hybrid species Carassius auratus gibelio (o) $\times$ Cyprinus carpio var. singuonensis $\left(0^{7}\right)$, which was produced in China in the 1980s. Since then this hybrid species has been one of the main freshwater aquaculture species in China due to its fast growth rate, easiness to culture and relative disease resistance. It is cultured in earthen ponds alone or together with grass carp Ctenopharyngodon idellus, silver carp Нypophthalmichthys molitrix, bighead carp Aristichthys nobilis, and bluntsnout bream Megalobrama amblycephala. In recent years, epidermal papillomas on the surfaces of scales, fins and opercula in 2 yr old or older $\mathrm{ACC}$ have been reported during low temperature seasons. The incidence of this disease varies widely and can be as high as $90 \%$ in some ponds. Even though the mortality of the disease is low, diseased fish at the market size invariably lose their commercial value, causing heavy economic losses to farmers.

Epidermal tumours have been reported in cyprinids including common carp Cyprinus carpio L. (Schubert 1964, 1966, Huang 1993), koi carp Cyprinus carpio (Sano et al. 1985). Reported etiologies of fish epidermal tumours include viruses (Schubert 1964, 1966, Winqvist et al. 1968, Carlisle 1977, Sano et al. 1985, Huang 1993, Herman et al. 1997, Graham et al. 2004), 
chemical agents (Black 1983, Chen et al. 1996, Beckwith et al. 2000) and some other unknown factors (Wolke \& Murchelano 1976). The objective of the present study is to describe the morphological features of the lesions, investigate the etiology and undertake transmission experiments.

\section{MATERIALS AND METHODS}

Fish. Diseased ACCs were obtained from several affected ponds in fish farms. Healthy ACCs were obtained live from fish farms in the Chongming county of Shanghai, China, or from markets without history of infections. Diseased and healthy fish for the aquarium experiments and diseased fish for the isolation of bacterial pathogens were transported live to Shanghai Ocean University and maintained in the aquaria. Lengths of diseased and healthy fish were measured and ranged from 17 to $23 \mathrm{~cm}$.

Clinical observation and epizootiology. The appearance and developmental processes of diseased fish were observed from October 2005 to September 2007. Epizootic investigation was made by visiting the fish farms and questioning farmers.

Etiological determination. Examination of parasites: Wet mounts of epidermal papillomas from the scales, fins and opercula, and of gills and internal organs of diseased fish were prepared and observed under a light microscope. Ten diseased fish were examined each month during the high prevalence season from September 2006 to March 2007.

Isolation of bacterial pathogens: Ten diseased fish were washed with sterile water. The surface of diseased fish was disinfected by swabbing with $75 \%$ alcohol and washed with sterile water again. The tumour surface was seared with a heated scalpel blade and the tumour tissue was sampled with an inoculating loop. The body cavity was opened by blunt-ended scissors. Bacterial isolation from kidney and liver was carried out with the same procedures as that used for sampling the tumour. In order to avoid the possibility of omission of some bacterial pathogens, different isolation media were used. They included a non-selective medium of nutrient agar (NA), containing 0.5 or $2 \% \mathrm{NaCl}$, for the majority of fish bacterial pathogens which are nonfastidious in their nutrient requirements, as well as the selective Shotts-Waltman medium and Ogawa's egg medium (Frerichs 1993), containing $2 \%(\mathrm{w} / \mathrm{v}) \mathrm{NaCl}$, for the growth of Yersinia ruckeri and Mycobacterium spp., respectively, which are fastidious in their nutrient requirements. Cultures were placed at 10,20 and $30^{\circ} \mathrm{C}$, respectively, for at least $72 \mathrm{~h}$ before the plates were examined for bacterial growth.
Tap water culture: 20 diseased fish were reared in an indoor aquarium containing $850 \mathrm{l}$ of tap water from February 2006 to May 2007 for about 15 mo under natural temperature. Fish were fed with a commercial dry pellet diet, and 70 to $100 \%$ of the water was changed daily. During the culture period, the symptoms and behaviour of diseased fish and water temperature were carefully monitored and recorded. 20 healthy fish in a control group were reared under the same conditions as the diseased fish.

Artificial infection: Tumour tissues were homogenized in a sterile grinder in phosphate-buffered saline (PBS) at a final dilution of 1:5. The cell debris was removed by centrifugation at $765 \times g$ for $10 \mathrm{~min}$. The supernatant was filtered through a $0.22 \mu \mathrm{m}$ Millipore membrane filter and used as the inoculum. Two groups of 14 healthy fish were separately reared in 2 aquaria containing $850 \mathrm{l}$ of tap water at 7 to $10^{\circ} \mathrm{C}$ in winter. Fish were fed with a commercial dry pellet diet, and 70 to $100 \%$ of the water was changed daily. Their scales were scarified by a scalpel. The scales of the 14 healthy fish in the experimental group were smeared with the filtrate, whereas the scales of the 14 healthy fish in the control group were smeared with PBS. Some portions of the filtrate were used for negative staining of viral particles for electron microscopic examination with $2 \%$ phosphotungstic acid at $\mathrm{pH} 6.8$.

Histopathological examination. Tumour tissues and gills were obtained from 10 diseased fish in winter when the disease appeared and from 10 diseased fish in the late spring when the tumour began to regress as water temperature increased.

Light microscopy: Tumours and gills from the diseased fish were removed with a scalpel and cut into 3 to $5 \mathrm{~mm}^{3}$ fragments and fixed in Bouin's solution for $24 \mathrm{~h}$, then washed with and preserved in $75 \%$ alcohol. After fixation, tissues were processed routinely in paraffin blocks, sectioned at 4 to $5 \mu \mathrm{m}$ and stained with haematoxylin and eosin (H\&E) for light microscopic examination. Tissue sections were also stained with Mann's method for inclusion body examination (Liu et al. 1983).

Transmission electron microscopy: Portions of the excised tumours and gills from diseased fish and tumour tissue on one of the scales from artificially infected fish were minced into small fragments of $1 \mathrm{~mm}^{3}$ and were pre-fixed in $3 \%$ glutaraldehyde in $0.1 \mathrm{M}$ cacodylate buffer $(\mathrm{pH} 7.3)$ at $4^{\circ} \mathrm{C}$ for $2 \mathrm{~h}$ and post-fixed in $1 \%$ osmium tetroxide in the same buffer at $4^{\circ} \mathrm{C}$, dehydrated through a graded ethanol series and embedded in Epon 812. Sections were cut using an LKB 2088 ultramicrotome. Ultrathin sections were stained with uranyl acetate and lead citrate and were examined under a JEM 100C-II (JEOL) transmission electron microscope. Virus sizes are expressed as mean $\pm \mathrm{SD}$. 


\section{RESULTS}

\section{Symptoms}

Epidermal papillomas occurred on the surface of scales, fins and opercula of adult fish (Figs. 1 \& 2). Some epithelia on the scales, fins or opercula were slightly thickened due to the proliferation of epidermal cells in early stages of the disease. Growing epidermal papillomas gradually spread to adjacent areas and merged together. The thickest parts of papillomas reached approximately $1.2 \mathrm{~cm}$. Heavily diseased fish had at least two-thirds of their body surface covered by epidermal papillomas. The colour of thickened epidermal papillomas was grayish-white or pinkish, depending on the extent of angiogenesis. Excessive mucus was produced to form a white mucus layer on the tumour surface when the fish were stressed by handling and crowding in the net or during transportation.

\section{Epizootiology}

Epidermal papillomas in ACCs were first found in October 2005. Since then, the epizootiology of the disease has been investigated. The area of fishponds with ACCs was 2000 ha in the Chongming county of Shanghai, China, among which the disease occurred in about 800 ha of ponds. The density of ACCs in the ponds which were cultured with other freshwater fish was approximately $15000 \mathrm{ha}^{-1}$. Epidermal papillomas were most prevalent in the late autumn and winter, as water temperatures declined. The papillomas were self-limiting and regressed as water temperature increased in late spring and summer. Epidermal papillomas were observed only in fish $2 \mathrm{yr}$ of age or older. The incidence varied considerably from ca. $5 \%$ to levels as high as $90 \%$ in the different ponds affected. The mortality of diseased fish was low at approximately $10 \%$. However, higher mortalities of diseased fish, associated with handling stress and crowding in the net or transportation, reached values higher than $95 \%$, depending on the degree of stress. Although 1 yr old or younger fish were always cultured together with adult diseased fish in the same earthen pond, no symptoms of the disease appeared in young fish. When other species - such as glass carp, silver carp, bighead carp and bluntsnout bream-were cultured with diseased ACCs in the same pond they did not develop the disease. Thus, the disease can be regarded as specific to ACC.

\section{Etiology}

Several Chilodonella species were the only parasites detected on the gills of diseased fish. No parasites were detected in tumour tissues and internal organs of these fish.

No bacterial pathogens were isolated from the tumours, kidneys and livers using various culture media. Various antibiotics had been used by farmers in some affected ponds to treat diseased fish but showed no effect.

In diseased fish reared in indoor aquaria from February 2006 to May 2007 under natural temperature conditions, the hyperplasia of tumours ceased to progress in April 2006 as water temperature increased to about $18^{\circ} \mathrm{C}$. As temperature further increased, tumours became dark, shrank in the late spring and disappeared in all diseased fish between June and July when water temperature was 28 to $32^{\circ} \mathrm{C}$. Tumours reappeared again in some fish in October when water temperature declined to about $20^{\circ} \mathrm{C}$ and enlarged as temperature further declined towards winter. The incidence of disease reoccurrence was $55.0 \%$. The control group of 20 healthy fish was not affected during the experimental period.

Artificial infection with a filtered tumour homogenate induced epidermal hyperplasia on the scales of 2 among 14 healthy fish after $35 \mathrm{~d}$ (14.3\%). The colour of the epidermal hyperplasia was grayish at first and grayish-black later, and the epidermis gradually thickened. However, the symptoms disappeared as water temperature increased in late spring. The control group was not affected during the experimental period.
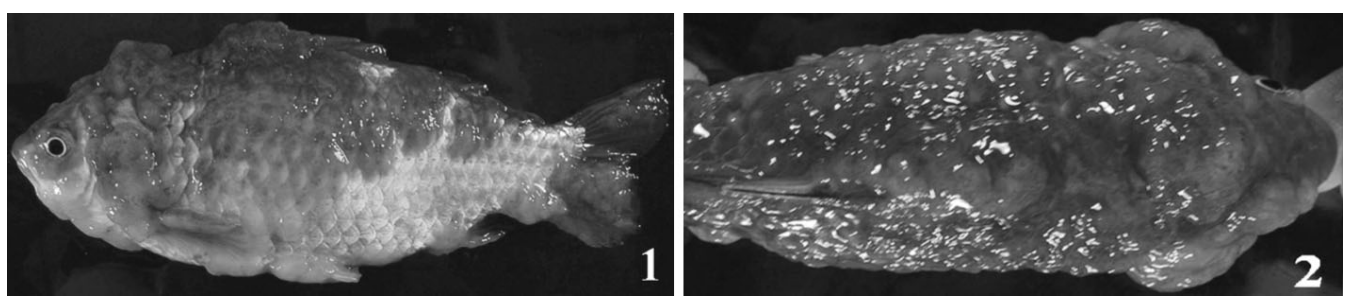

Figs. 1 \& 2. Carassius auratus gibelio (o) $\times$ Cyprinus carpio var. singuonensis $\left(0^{\prime}\right)$. Fig. 1. Lateral view of a diseased adult with epidermal papillomas on the surface of scales, fins and opercula. Fig. 2. Dorsal view of a heavily diseased adult with epidermal papillomas 


\section{Histopathological examination}

\author{
Light microscopy
}

The epithelial cell layer of normal epidermis of ACC is about 4 to 8 cells thick, below which is a thin layer of connective tissue, lying immediately adjacent to the scales, fins and opercula. The epidermal papillomas were up to 20 times thicker than the normal epidermis. In early stages of the lesion, connective tissue and epithelial tumour cells in the basal layer epithelium were hyperplastic. The direction of the proliferative expansion of connective tissue was opposite to that of the epithelial tumour cells. Hyperplastic connective tissue with abundant capillaries gradually protruded into the layer of hyperplastic epithelial tumour cells to form papillomas (Fig. 3). At the next stage, both epithelial tumour cells and connective tissue further proliferated and expanded in opposite directions. Multiple layers of proliferating epidermal tumour cells were surrounded and demarcated by a stratum of connective tissue to form larger papillomas (Figs. 3, 4 \& 5), projecting above the scales, fins and opercula. A number of capillaries surrounded by radiating epithelial tumour cells were also found in the tumour tissues (Fig. 6). Most of the mucous cells were arranged in clusters near the middle of the papillomas (Figs. 4 \& 5) and partly extended towards the tumour surface (Fig. 4). They usually lysed after secreting mucus (Figs. $7 \& 8$ ), leaving behind the mucus and empty spaces (Figs. 4 \& 9). The nuclei of epithelial tumour cells were condensed, irregular in shape and variable in size. Bi-nucleated cells and one or more grooves on a nucleus were common. Numerous granulocytes and lymphocytes infiltrated the tumour tissue where a severe inflammatory response was observed (Fig. 10). Necrosis of epithelial tumour cells occurred when the tumour regressed as water temperatures increased in late spring. Many necrotic foci were heavily infiltrated by granulocytes and lymphocytes (Fig. 11). There were no inclusion bodies in the cytoplasm or nuclei of tumour cells.

Most of the secondary gill lamellae were normal in the diseased fish; only a few lamellae were thickened. In the secondary gill lamellae of normal gills, there was 1 layer of squamous epithelial cells at the periphery, whilst the epithelial cells in hyperplastic secondary gill lamellae of diseased fish proliferated to $2-4$ cells in thickness (Fig. 12).

\section{Transmission electron microscopy}

Viral particles were observed in the filtered tumour homogenate after negative staining (Fig. 13b) and in the epithelial cells of (1) tumours and gills in the diseased fish and (2) tumour tissue on one of the scales from artificially infected fish. Enveloped viral particles were circular to hexagonal with a circular central core (Fig. 13a) in the cytoplasm. The cytoplasm contained multiple aggregates of enveloped viral particles which were $118.18 \pm 10.53 \mathrm{~nm}(\mathrm{n}=22)$ in diameter. Nucleocapsids were $78.64 \pm 7.74 \mathrm{~nm}(\mathrm{n}=22)$ in diameter. Empty capsids were visible both in the nucleus and the cytoplasm (Fig. 14). The presence of the enveloped viruses in the cytoplasm and empty capsids of viruses in the nucleus and the morphology and size of viruses suggested that the viral particles were a herpes-like virus. The shape of the nuclei of the infected cells was irregular and their size varied. Mitochondria, endoplasmic reticulum and other cytoplasmic organelles of the tumour cells were reduced in number or absent. Two or 3 deep grooves in 1 nucleus were commonly observed. Nucleoli were condensed to become highly electron-dense (Fig. 15). Numerous granulocytes infiltrated into the tumour tissue, where necrosis of epithelial tumour cells occurred (Fig. 16). As water temperatures increased in late spring, many tumour cells

Figs. 3 to 12. Carassius auratus gibelio (o) $\times$ Cyprinus carpio var. singuonensis ( $\left.0^{\natural}\right)$. Histopathological examination under light microscopy. Fig. 3. Vertical section of a tumour showing connective tissue with abundant capillaries (solid arrows) lying immediately adjacent to the scale (solid arrowhead). Hyperplastic connective tissue (open arrows) protrudes into the layer of hyperplastic epithelial tumour cells to form a papilloma. Scale bar: $50 \mu \mathrm{m}$. Fig. 4. Vertical section of a tumour showing mucous cells in clusters (open arrows) near the middle of a papilloma (solid arrowhead) and mucus (solid arrow) left behind after secretion. Scale bar: $100 \mu \mathrm{m}$. Fig. 5. Horizontal section of a tumour showing mucous cells in clusters (solid arrows) near the middle of each fold (open arrows). Scale bar: $100 \mu \mathrm{m}$. Fig. 6. Capillaries (solid arrows) surrounded by radiating epithelial tumour cells (open arrow). Scale bar: $50 \mu \mathrm{m}$. Fig. 7. Initial stage of secreting mucus of mucous cell (solid arrowhead). Numerous granulocytes (solid arrows) and lymphocytes (open arrows) are visible in tumour tissue. Scale bar: $20 \mu \mathrm{m}$. Fig. 8. Lysed mucous cells (solid arrows) after secreting mucus. Scale bar: $40 \mu \mathrm{m}$. Fig. 9. Mucus (solid arrow) and empty space (open arrow) left behind after the lysis of mucous cells. Scale bar: $20 \mu \mathrm{m}$. Fig. 10. Nuclei of epithelial tumour cells irregular in shape and in size (solid arrowhead) showing one or more grooves (open arrow) on a nucleus. Also visible are condensed nucleoli (thin solid arrows) and infiltration of granulocytes (solid arrows) and lymphocytes (open arrowhead) in tumour tissue. Scale bar: $10 \mu \mathrm{m}$. Fig. 11. Necrosis of epithelial tumour cells (solid arrowheads) on the surface of a tumour. Note infiltration of granulocytes (solid arrows) and lymphocytes (open arrows) in tumour tissue. Scale bar: $20 \mu \mathrm{m}$. Fig. 12. Proliferated epithelial cells (2 to 4 cells thick) of secondary gill lamellae (solid arrow). Scale bar: 


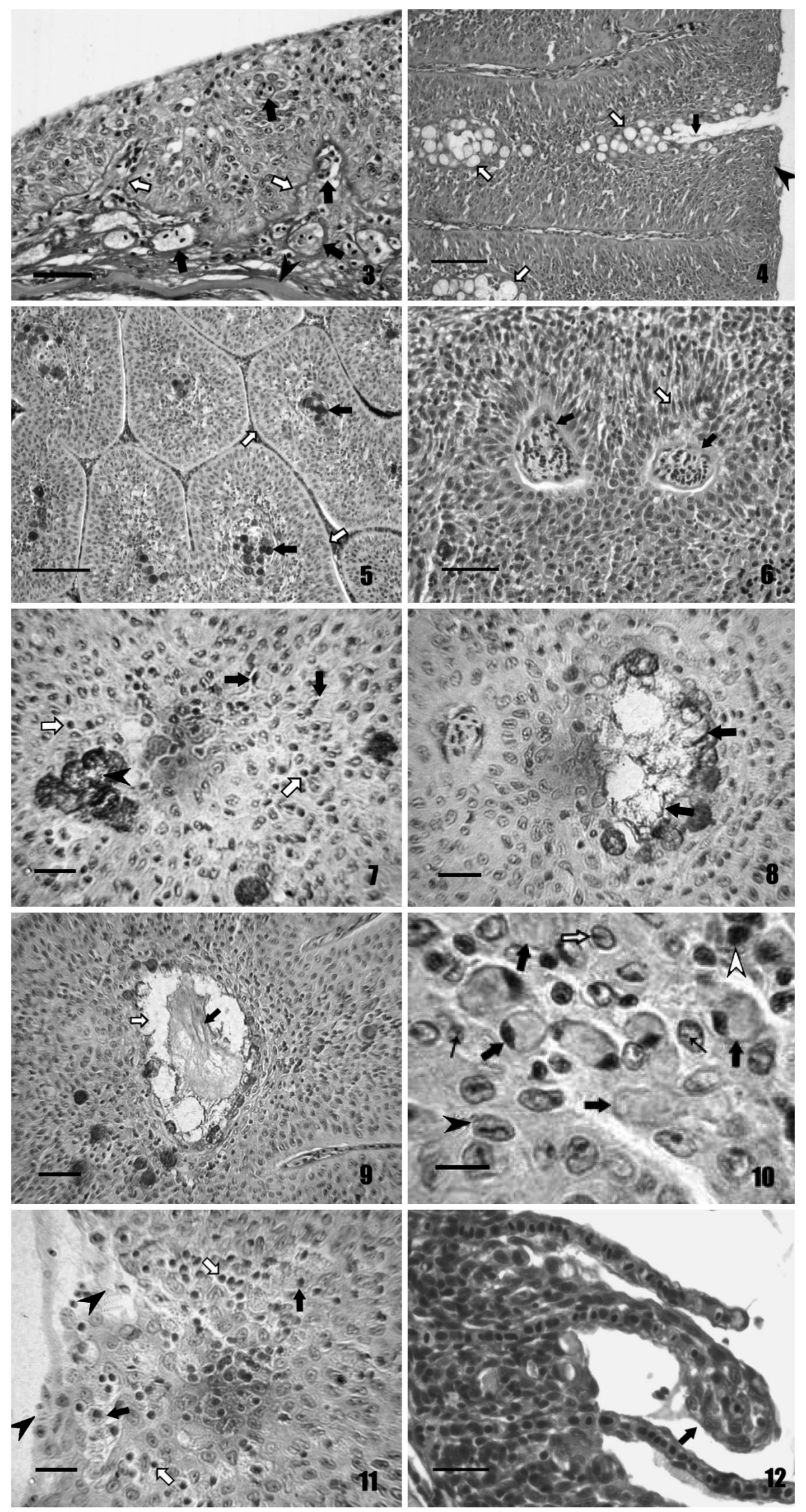



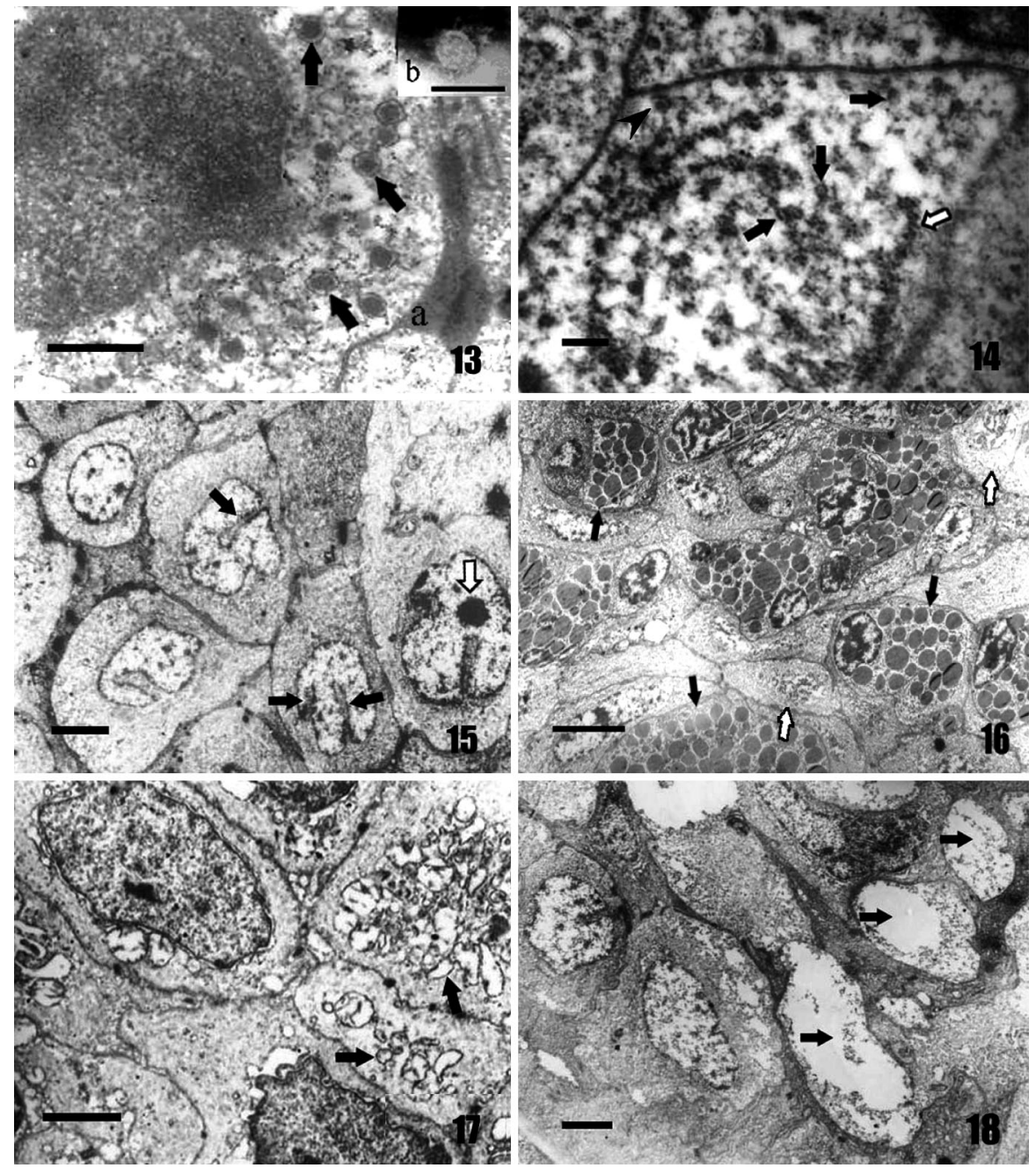

Figs. 13 to 18. Carassius auratus gibelio (o) $\times$ Cyprinus carpio var. singuonensis $\left(0^{7}\right)$. Histopathological examination under transmission electron microscopy. Fig. 13. (a) Free virus particles (solid arrows) in the cytoplasm of an epithelial tumour cell. Scale bar: $400 \mathrm{~nm}$. (b) Negatively stained (phosphotungstic acid) released virus from the filtered supernatant of homogenized tumour tissue. Scale bar: $200 \mathrm{~nm}$. Fig. 14. Broken membrane (open arrow) of a nucleus. Empty capsids (solid arrows) in the nucleus and cytoplasm and partially enveloped virus in the cytoplasm (solid arrowhead) are also shown. Scale bar: $300 \mathrm{~nm}$. Fig. 15. Nuclei of epithelial tumour cells, irregular in shape. One or more grooves (solid arrows) on nuclei can be seen. Cytoplasmic organelles of the tumour cells are reduced or absent. Note condensed nucleolus (open arrow). Scale bar: $2.5 \mu \mathrm{m}$. Fig. 16. Granulocytes (solid arrows) infiltrated into tumour tissue and necrotic tumour cells (open arrows). Scale bar: 5.0 um. Fig. 17. Membranes of nuclei, broken to form many small bubble-like structures (solid arrows). Scale bar: $2.0 \mu \mathrm{m}$. Fig. 18. Empty spaces (solid arrows) left behind after the disappearance of nuclei and nucleoplasm. Scale bar: $2.5 \mu \mathrm{m}$

underwent necrosis. The membranes of their nuclei broke to form many small bubble-like structures (Fig. 17). The nuclei and nucleoplasm of tumour cells eventually disappeared (Fig. 18).

\section{DISCUSSION}

The causes of epidermal tumours are various. Chemical agents and pathogens, including viruses, bacteria and parasites, have been reported to induce epidermal tumours, not only in aquatic animals (Walker 1969, Black 1983, Okada \& Fujimoto 1984, Huang 1993, Chen et al. 1996, Beckwith et al. 2000, Huh et al. 2005) but also in other vertebrate animals (Wang et al. 1997, Pledger 2005). The most common causes of epidermal tumours are chemical agents and viruses. In the present study, the symptoms disappeared in summer in 20 diseased fish and reappeared in 11 fish in late autumn, as water temperature declined, during 15 mo of culture in an indoor aquarium with a tapwater supply. The periodic change of symptoms in diseased fish reared in 
Table 1. Epidermal tumour disease reported in allogynogenetic crucian carp (present study) and other aquatic animals. Sizes of enveloped viral particles and nucleocapsids, as well as presence or absence of cytoplasmic and intranuclear inclusion bodies (in tumour cells) are shown; nd: no data

\begin{tabular}{|c|c|c|c|c|c|}
\hline \multirow[t]{2}{*}{ Host } & \multirow[t]{2}{*}{ Description } & \multicolumn{2}{|c|}{ Diameter (nm) } & \multirow{2}{*}{$\begin{array}{l}\text { Inclusion } \\
\text { bodies }\end{array}$} & \multirow[t]{2}{*}{ Source } \\
\hline & & Viral particles & Nucleocapsids & & \\
\hline $\begin{array}{l}\text { Allogynogenetic } \\
\text { crucian carp }\end{array}$ & & $118^{\mathrm{a}}$ & $79^{\mathrm{b}}$ & No & Present study \\
\hline Carp & Carp pox disease & $\sim 140$ & $\sim 110$ & Yes & Schubert $(1964,1966)$, Huang (1993) \\
\hline Koi carp & & 190 & 113 & nd & Sano et al. (1985) \\
\hline Rainbow smelt & & $160-200$ & $80-90$ & nd & Herman et al. (1997) \\
\hline Atlantic salmon & & $125-150$ & nd & nd & Carlisle (1977) \\
\hline Northern pike & & $\begin{array}{l}120-150 \\
120-240^{\mathrm{c}}\end{array}$ & nd & nd & $\begin{array}{l}\text { Winqvist et al. (1968), Graham et } \\
\text { al. }(2004)^{\mathrm{c}}\end{array}$ \\
\hline Seals & Seal pox disease & $\begin{array}{l}300 \times 140^{\mathrm{d}} \\
250-300^{\mathrm{e}}\end{array}$ & nd & Yes & Okada \& Fujimoto (1984) \\
\hline
\end{tabular}

the indoor aquarium was similar to that in the earthen ponds. The control group of 20 healthy fish was not affected during the experimental period. This phenomenon indicates that water quality was not a direct cause of the disease reported in the present study. No parasitic or bacterial pathogens were found in the epidermal papillomas. Epidermal hyperplasia appeared in the infected areas of healthy fish after artificial infection with the filtrate containing the viral particles, even though the disease was not induced in all experimental fish. Electron microscopy of hyperplastic epithelial cells showed herpes-like viruses in the cytoplasm. Based on these results, it can be concluded that the disease was very likely induced by a herpes-like virus and not by parasites, bacteria or chemical agents in the water. This is the first report of epidermal papillomas in ACC associated with a virus.

According to the morphology and size of the virus, and the lack of inclusion bodies in the cytoplasm and nuclei of epithelial tumour cells, the disease reported in the present study is different from carp pox disease and other epidermal tumour diseases of aquatic animals reported in the literature. These data are summarized in Table 1 and suggest that epidermal papillomas in ACC may in fact be caused by a new virus.

Mucous cells were completely absent in the epidermal tumour in the sheat fish Silurus glanis, when compared with the epidermis of normal healthy skin (Lucky 1970). However, mucous cells increased in number in the epidermal papillomas of the disease reported in the present study and most of them were aggregated in clusters. Mucus secreted by mucous cells reached the tumour surface through the empty spaces formed after secretion. This may be the reason for the common symptom of a white mucus layer on the tumour surface when fish were stressed by handling and crowding in the net or during transportation.

Infiltration by numerous granulocytes and lymphocytes was observed in tumour tissues. The inflammatory response may play an important role in limiting tumour growth and may cause a regression of the epidermal papillomas as water temperatures increases in late spring and summer. However, changes in temperature are likely to be a major factor in viral replication as well. The speculation on the role of the inflammatory response is supported by the fact that necrosis of tumour cells was commonly found in tumour tissue sections. However, other mechanisms involved in the regression of the tumour should be investigated in the future.

Acknowledgements. This work was funded by the Shanghai Agricultural Commission (Grant No. 2006-6-6) and Shanghai Leading Academic Discipline Project (Grant No. Y1101).

\section{LITERATURE CITED}

Beckwith LG, Moore JL, Tsao-Wu GS, Harshbarger JC, Cheng KC (2000) Ethylnitrosourea induces neoplasia in zebrafish (Danio rerio). Lab Invest 80:379-385

Black JJ (1983) Field and laboratory studies of environmental carcinogenesis in Niagara River fish. J Gt Lakes Res 9: $326-334$

Carlisle JC (1977) An epidermal papilloma of the Atlantic salmon II: ultrastructure and etiology. J Wildl Dis 13: 235-239

Chen HC, Pan IJ, Tu WJ, Lin WH, Hong CC, Brittelli MR (1996) Neoplastic response in Japanese medaka and channel catfish exposed to N-methyl-N'-nitro-N-nitrosoguanidine. Toxicol Pathol 24:696-706

Frerichs GN (1993) Isolation and identification of fish bacterial pathogens. In: Inglis V, Roberts RJ, Bromage NR (eds) 
Bacterial diseases of fish. Blackwell Scientific Publications, London, p 257-283

Graham DA, Curran WL, Geoghegan F, McKiernan F, Foyle KL (2004) First observation of herpes-like virus particles in northern pike, Esox lucius L., associated with bluespotlike disease in Ireland. J Fish Dis 27:543-549

Herman RL, Burke CN, Perry S (1997) Epidermal tumors of rainbow smelt with associated virus. J Wildl Dis 33: 925-929

Huang QY (1993) Diseases of aquatic animals. Shanghai Science and Technical Press, Shanghai

Huh MD, Thomas CD, Udomkusonsri P, Noga EJ (2005) Epidemic trichodinosis associated with severe epidermal hyperplasia in largemouth bass, Micropterus salmoides, from North Carolina, USA. J Wildl Dis 41:647-653

Liu JM, Yan QH, Lu YJ, Dou ZhL, Wang ZhM (1983) Theory and practice of staining methods on pathological tissues. People's Medical Publishing House, Beijing

Lucky Z (1970) Pathological changes with pox (epithelioma papulosum) in the sheat fish (Silurus glanis). Acta Vet Brno 8(Suppl 1):1-86

Okada K, Fujimoto Y (1984) The fine structure of cytoplasmic and intranuclear inclusions of seal pox. Jpn J Vet Sci 46: 401-404

Editorial responsibility: Thomas Lang,

Cuxhaven, Germany
Pledger A (2005) Avian pox virus infection in a mourning dove. Can Vet J 46:1143-1145

Sano T, Fukuda H, Furukawa M, Hosoya H, Moriya Y (1985) A herpesvirus isolated from carp papilloma in Japan. In: Ellis AE (ed) Fish and shellfish pathology. Academic Press, London, p 307-311

Schubert G (1964) Elektronenmikroskopische Untersuchungen zur Pockenkrankheit des Karpfens. Z Naturforsch 19b:675-682

Schubert GH (1966) The infective agent in carp pox. Bull Off Int Epizoot 65:1011-1022

Walker R (1969) Virus associated with epidermal hyperplasia in fish. Natl Cancer Inst Monogr 31:195-207

Wang WY, He J, Zhang ShF, Yao M (1997) Studies on tumor induction in mice by the infection of bacterium and its Lform. Chinese Journal of Microecology 9:40-41

Winqvist G, Ljungberg O, Hellstroem B (1968) Skin tumors of northern pike (Esox lucius L.). II. Viral particles in epidermal proliferations. Bull Off Int Epizoot 69:1023-1031

Wolke RE, Murchelano RA (1976) A case report of an epidermal papilloma in Mustelus canis. J Wildl Dis 12: 167-171

Zhou WSh, Liu L (2004) Issues on utilization of Latin names of fish in edition. Fish Sci 23:43-44

Submitted: March 11, 2008; Accepted: September 16, 2008

Proofs received from author(s): January 14, 2009 